\title{
Hygiene practices for patients with HIV/AIDS
}

\author{
Práticas de higiene para pacientes com HIV/AIDS \\ Prácticas de higiene para los pacientes con VIH/SIDA
}

\author{
Gilmara Holanda da Cunha ${ }^{a}$ \\ Thelma Leite de Araujo ${ }^{b}$ \\ Francisca Elisângela Teixeira Limac \\ Tahissa Frota Cavalcante ${ }^{d}$ \\ Marli Teresinha Gimeniz Galvão ${ }^{e}$
}

DOl: $\quad$ http://dx.doi.org/10.1590/1983-

1447.2014.03.44928

\footnotetext{
a Nurse. PhD in Pharmacology. Adjunct Professor in the Department of Nursing of the Federal University of Ceará. Fortaleza, Ceará, Brazil.

${ }^{b}$ Nurse. PhD in Nursing. Full Professor in the Department of Nursing of the Federal University of Ceará. Fortaleza, Ceará, Brazil.

c Nurse. PhD in Nursing. Adjunct Professor in the Department of Nursing of the Federal University of Ceará. Fortaleza, Ceará, Brazil.

${ }^{d}$ Nurse. PhD in Nursing. Adjunct Professor at Universidade da Integração Internacional da Lusofonia AfroBrasileira (UNILAB). Redenção, Ceará, Brazil.

e Nurse. PhD in Tropical Diseases. Associate Professor in the Department of Nursing of the Federal University of Ceará. Fortaleza, Ceará, Brazil.
}

\begin{abstract}
The objective of this study was to analyze the scientific production on health interventions related to hygiene for adults with HIV/ AIDS. An integrative literature review was performed using six databases in June 2013. The descriptors AIDS and Hygiene were used, in Portuguese, English or Spanish. A total of 682 articles were found and 16 were selected. Personal hygiene practices were identified, such as hand washing, showers, tooth brushing and quitting smoking. Food hygiene practices involved washing food and kitchen utensils, using treated water, conserving and cooking food. Environmental hygiene took into account raising domestic animals, control of disease vectors, household cleanliness, waste disposal and basic sanitation. In conclusion, these specific hygiene interventions can be applied to the general population and, especially, to people with HIV/AIDS, due to immunosuppression.
\end{abstract}

Descriptors: HIV. Acquired Immunodeficiency Syndrome. Hygiene. Health promotion. Nursing.

\section{RESUMO}

0 objetivo do estudo foi analisar as produções científicas sobre as intervenções de saúde relacionadas à higiene de adultos com HIV/ AIDS. Realizou-se revisão integrativa da literatura, por meio de seis bases de dados, no mês de junho de 2013. Utilizou-se os descritores AIDS e Higiene, nos idiomas português, inglês ou espanhol. Foram encontrados 682 artigos e selecionados 16. Identificaram-se cuidados de higiene pessoal, como a lavagem de mãos, banho, escovação dos dentes e abandono do hábito tabagista. Os cuidados de higiene alimentar envolveram a limpeza dos alimentos e utensílios domésticos, utilização de água tratada, conservação e cozimento dos alimentos. A higiene ambiental considerou os cuidados na criação de animais domésticos, controle de vetores de doenças, limpeza do domicílio, descarte de resíduos e saneamento básico. Conclui-se que as intervenções de higiene identificadas podem ser aplicáveis à população geral, e principalmente às pessoas que vivem com HIV/AIDS, devido à imunossupressão.

Descritores: HIV. Síndrome de imunodeficiência adquirida. Higiene. Promoção da saúde. Enfermagem.

\section{RESUMEN}

El objetivo del estudio fue analizar las producciones científicas sobre intervenciones de salud relacionados con la higiene de adultos con VIH/SIDA. Se realizó una revisión de la literatura a través de seis bases de datos en junio de 2013. Se utilizaron los descriptores SIDA e Higiene, en portugués, inglés o español. Se encontraron 682 artículos y se seleccionaron 16. Se identificaron higiene personal, como lavarse las manos, bañarse, cepillarse los dientes y no fumar. El cuidado de higiene de alimentos involucrados, limpiar alimentos y artículos domésticos, el uso de agua tratada, la conservación y cocción de alimentos. La higiene del medio ambiente consideró la crianza de animales domésticos, el control de vectores de enfermedades, la limpieza del hogar, la eliminación de residuos y saneamiento. Se concluye que las intervenciones de higiene pueden ser aplicables a la población general, especialmente, para las personas que viven con el VIH/SIDA, debido a la inmunosupresión.

Descriptores: VIH. Síndrome de inmunodeficiencia adquirida. Higiene. Promoción de la salud. Enfermería. 


\section{口INTRODUCTION}

Infection by the human immunodeficiency virus (HIV) is a high profile health problem, due to its pandemic nature and severity. In Brazil, the first cases of acquired immunodeficiency syndrome (AIDS) appeared in the 1980s, among homosexuals, intravenous drug users and hemophiliacs. From 1980 to June 2012, 656,701 cases of AIDS were reported to the Notifiable Diseases Information System (SINAN, as per its acronym in Portuguese) $)^{(1)}$. Currently, the epidemic in the country is stable, concentrated among vulnerable sectors of the population ${ }^{(2)}$.

The reduction in morbidity and mortality by AIDS has occurred due to the introduction of the antiretroviral therapy (ART) in 1996. Brazil was the first developing country to adopt a public policy providing access to ART ${ }^{(3)}$. Even though ART is provided for free, the economic and political aspects of the populations in which AIDS has been spreading must be taken into account. Everyone may be subject to risk behavior, but the majority of the cases of AIDS occur in poor countries, suggesting a connection with low economic levels and lack of information ${ }^{(2,4)}$.

Since ART increases the post-diagnosis life expectancy of people with HIV/AIDS, and given the chronic nature of the disease, health care becomes significantly important for these individuals, who need individual attention so that they will be able to develop skills to care for themselves and achieve improved quality of life $\mathrm{e}^{(5)}$.

In terms of developing self-care skills, this can be accomplished through educational strategies related to adopting a healthy lifestyle, which becomes essential for those living with chronic diseases, such as AIDS. The care given to these patients is complex, since they have various problems, among which are inadequate hygiene habits. Research shows that deficient self-care and insufficient knowledge are related to lack of interest to learn, low educational level and lack of skill with information resources ${ }^{(6-7)}$.

Hygiene consists of a set of knowledge necessary to prevent sickness and enhance people's safety. At the same time, personal, social and cultural factors have an influence on hygiene practices. In institutions and households, nurses determine the ability of patients to provide self-care, promote hygiene practices according to their different needs and adapt hygiene techniques and approaches $^{(8)}$.

The term hygiene is Greek in origin and means "that which is healthy", deriving from the name of the Greek god of health - Hygeia(9). This term can be combined with other words that expand its meaning: personal hygiene, food hygiene, collective hygiene, mental hygiene and environmental hygiene. At the turn of the $19^{\text {th }}$ century, the concept of hygiene appeared for the first time, understood as "the art of preserving life". Subsequently, Florence Nightingale applied these hygiene practices to the wounded in the Crimean War and was able to lower mortality rates. Nightingale's environmental model included ventilation, heating, light, noise, change of environment, clean beds and bedding, personal hygiene, nutrition and food intake(8).

In 2006, the Pact for Life, in Defense of the Unified Health System and Management was signed, establishing priorities that have had an impact on the health of the Brazilian population. This initiative stemmed from the need to broaden the access to quality health services which prioritize health and encourage healthy lifestyles, where hygiene plays an essential role ${ }^{(9)}$.

As professionals, nurses provide care in different areas of health to people with HIV/AIDS. They need to understand the disease, improve routine behaviors, adopt precautionary measures to avoid accidental exposure to the virus and acquire knowledge about clinical treatment. Thus, through observing the needs of patients, educational strategies can be implemented to promote health and disease prevention, including guidelines on proper hygiene.

HIV infection is a serious public health problem and constitutes a major challenge due to the absence of a cure, in addition to the social and economic barriers that interfere with adhering to the therapeutic regimen. In light of this and in order to enhance the care of people suffering from HIV/AIDS, the objective of this study was to analyze the scientific production on health interventions related to the hygiene of adults with HIV/AIDS.

\section{$\square$ METHOD}

It consists of an integrative literature review, which was developed in six stages: 1. Formulation of the guiding question; 2. Literature review; 3. Data collection; 4. Critical analysis of the studies; 5 . Discussion of the results; 6 . Presentation of the integrative review ${ }^{(10)}$. The study guiding question was: Which hygiene-related health practices are directed toward adults with HIV/AIDS?

Articles were selected from six databases: Latin American and Caribbean Center on Health Sciences Information (LILACS), Scientific Electronic Library Online (SciELO), Medical Literature Analysis and Retrieval System Online (MEDLINE), Cumulative Index to Nursing and Allied Health Literature (CINAHL), SCOPUS and COCHRANE. The articles 
were collected in June 2013, using the following Health Science Descriptors (DeCS) from the Virtual Health Library $(\mathrm{VHL})$ and from the Medical Subject Headings (MeSH) of the National Library of Medicine: AIDS and Hygiene, in Portuguese, English or Spanish.

The inclusion criteria were: complete papers electronically available in Portuguese, English or Spanish, involving the issue of hygiene practices for adults with HIV/AIDS, regardless of the year of publication. The exclusion criteria consisted of letters to the editor.

The levels of evidence were determined as follows: 1: Evidence from the systematic review or meta-analysis of randomized controlled clinical trials or arising from clinical guidelines based on systematic reviews of randomized controlled clinical trials; II: Evidence derived from at least one randomized controlled clinical trial; III: Evidence obtained from non-randomized clinical trials; IV: Evidence from cohort and case-control studies; $\checkmark$ : Evidence originating from the systematic review of descriptive and qualitative studies; VI: Evidence derived from a descriptive or qualitative study; VII: Evidence stemming from the opinions of authorities or reports of expert committees ${ }^{(11)}$.

The number of articles selected from the databases is shown in Table 1. A total of 666 articles were excluded because they did not comply with the guiding question of the study. Repeated articles were also excluded. Most of the studies included precautions that health professionals or the general population should take in order not to expose themselves to HIV. This research, however, focused on health practices to enhance the quality of life of adults with HIV/AIDS.

The 16 selected articles were analyzed through an organized approach to consider the accuracy and characteristics of each study, by looking at the methodological development, proposed intervention or care, results, conclusion and level of evidence. Healthcare measures related to hygiene were grouped in three categories: personal hygiene, food hygiene and environmental hygiene. The fin- dings were discussed based on the scientific literature on the subject.

With respect to ethical concerns, the texts of the articles and copyrights were respected, and no changes were made to their content for the benefit of the study done by the authors of this paper.

\section{RESULTS}

The year of publication of the 16 articles ranged from 2002 to 2013, with eight papers published in European countries ${ }^{(12-19)}$, five in the United States ${ }^{(20-24)}$, two in Brazil ${ }^{(25-26)}$ and one in India ${ }^{(27)}$. In terms of levels of evidence ${ }^{(11)}$, they were distributed as follows: four Level |(13,15-17), one Level I|(21), one Level III ${ }^{(14)}$, eight Level V|(18-20,22-26) and two Level VII ${ }^{(12,27)}$. The majority of the health interventions related to the hygiene of adults with HIV/AIDS focused on food hygiene, totaling 19 health practices. Personal hygiene accounted for eight health practices and environmental hygiene for seven.

Chart 1 presents the personal hygiene interventions, which involve body, oral cavity and teeth hygiene, where the main concern is the development of oral fungal diseases and the detection of SDTs, such as infection by the human papillomavirus (HPV). The need to quit smoking was characterized as a personal hygiene measure, due to the harm it can cause to the lungs and the body in general.

Food hygiene interventions involved aspects related to the washing of food and kitchen utensils, in addition to the correct way to prepare food. Aspects regarding the characteristics of food when purchased, temperature control, preservation and storage were also found in the articles. The need to use treated water for drinking and washing food and kitchen utensils was likewise noted (Chart 2).

Some interventions need to be performed by health professionals who care for people with HIV/AIDS, such as providing advice on food safety ${ }^{(14,25)}$ as well as information

Table 1 - Articles that were found and selected. Fortaleza, Ceará, 2013.

\begin{tabular}{lccccccc} 
Articles/Database & LILACS & SciELO & MEDLINE & CINAHL & SCOPUS & COCHRANE & Total \\
Found & 183 & 21 & 92 & 109 & 170 & 107 & 682 \\
Excluded & 181 & 21 & 90 & 106 & 165 & 103 & 666 \\
Selected & 2 & 0 & 2 & 3 & 5 & 4 & 16 \\
\hline
\end{tabular}


Chart 1 - Health interventions related to personal hygiene for people with HIV/AIDS. Fortaleza, Ceará, 2013.

\section{Health interventions related to personal hygiene}

1. Wash hands with soap and water before and after meals and after using the bathroom ${ }^{(15-19,21,25-26) \text {. }}$

2. Shower daily with soap and water and dry off with a clean towel ${ }^{(18,21)}$.

3. Perform dental hygiene using a soft toothbrush and toothpaste at least two or three times per day (after breakfast, lunch and dinner) ${ }^{(12,14,24)}$.

4. Clean between the teeth daily using dental floss or an interdental brush ${ }^{(24)}$.

5. Replace toothbrush every three or four months, or before, if necessary ${ }^{(24)}$.

6. Use antibacterial mouthwashes ${ }^{(24)}$.

7. Visit the dentist regularly to remove plaque, get teeth cleaned and do an oral examination ${ }^{(14,23-24)}$.

8. Do not smoke(24).

Source: Research data

Chart 2 - Health interventions related to food hygiene for people living with HIV/AIDS. Fortaleza, Ceará, 2013.

\section{Health interventions related to food hygiene}

1. Wash hands with soap and water before and after handling any food ${ }^{(17-21,26)}$.

2. Avoid eating food in places with questionable cleanliness standards $s^{(14,26)}$.

3. Do not use the same cutting board for cutting raw meat and raw or cooked food ${ }^{(26)}$.

4. Properly disinfect food that will be consumed and the kitchen utensils used for preparing it, as well as wash the sponge that was used ${ }^{(26)}$.

5. Disinfect leafy vegetables in a sodium hypochlorite solution or another appropriate substance ${ }^{(26)}$.

6. Use only chlorinated, boiled or filtered water(13-16,19,26), and do not drink water from wells or springs(20,25-26).

7. When food shopping, pick the meats last and place them in a separate basket to avoid them from thawing in the store(26).

8. Do not take more than 30 minutes, preferably, to get home from the store where frozen or chilled foods were purchased, so that they can be stored in the freezer or refrigerator ${ }^{(26)}$.

9. Do not leave raw meat out of the refrigerator for longer than two hours ${ }^{(26)}$.

10. Do not leave out food prepared at room temperature for longer than two hours ${ }^{(26)}$.

11. Thaw food in the refrigerator(26).

12. Always examine food labels to check the expiration date, composition and overall condition of the packaging ${ }^{(26)}$.

13. Inspect the shells of eggs; do not eat undercooked eggs ${ }^{(20,26)}$.

14. Avoid buying meat from street vendors or from questionable sources ${ }^{(20,26)}$.

15. Do not consume unprocessed, raw or unpasteurized milk(20,26).

16. Do not eat raw or rare meat $(20,22,26,27)$.

17. Avoid consuming cheeses that have a soft consistency (brie, camembert, fresh) ${ }^{(20)}$.

18. Only use cheese and yogurt made from pasteurized milk(20).

19. Maintain a balanced diet with limits on sugar in order to prevent cavities(24).

Source: Research data

on common symptoms of water and food-related diseases, such as fever, itching, nausea, vomiting and diarrhea ${ }^{(26)}$.

Environmental hygiene involved aspects related to household cleanliness, handling of domestic animals and connection of the house to the public water supply network and having a sewerage system. Water supply is comprised of the activities and facilities needed to receive drinking water from the public water supply network ranging from collection to building connections and measuring instruments. The sewerage system in- 
Chart 3 - Health interventions related to environmental hygiene for people living with HIV/AIDS. Fortaleza, Ceará, 2013.

\section{Health interventions related to environmental hygiene}

1. Avoid raising domestic animals(25-26)

2. Do not handle pets while preparing meals ${ }^{(20)}$.

3. Safely dispose of domestic animal waste in the garbage ${ }^{(27)}$.

4. Use vector control measures (insects, animals)(22).

5. Keep the house clean ${ }^{(25)}$.

6. Have the house connected to the public water supply network ${ }^{(13,16,18-19,21,25)}$.

7. Have a sewerage system in the house ${ }^{(16,19,21)}$.

Source: Research data

volves collection, transport and adequate final disposal of sewage, ranging from building connections to final discharge into the environment. The information is presented in Chart 3.

Many of the hygiene interventions identified in the studies involving HIV/AIDS are applicable to the general population. However, due to immunosuppression in these individuals, greater adherence to the aforementioned interventions is necessary, in order to avoid health complications and insufficient self-care. Education aimed at promoting health is also needed.

\section{DISCUSSION}

Although HIV can infect many tissues, there are two main targets: the immune system and central nervous system. Profound immunosuppression results primarily from the infection of T CD4+ cells and their loss, as well as dysfunction of the T cells that survive. Macrophages and dendritic cells are also targets of HIV. There is evidence that the CD4 molecule is a high-affinity receptor for HIV. This explains the tropism of the virus by $T$ CD4+ cells and other CD4 + cells, especially monocytes/macrophages and dendritic cells ${ }^{(28)}$.

HIV/AIDS presents profound challenges for health professionals, due to scarcity of resources, limited infrastructure and the low socioeconomic and educational level of most patients ${ }^{(6-7)}$. Therefore, guidelines about proper hygiene practices are essential for everyone, especially those who are immunocompromised due to HIV infection.

In regard to nursing, it is important to develop strategies that meet the needs of these patients. However, the context in which each individual lives, their personal characteristics and the available resources they have in their daily lives must be taken into account. An analysis of these factors results in health interventions that will more likely be developed properly.

Based on this research, personal, food and environmental hygiene interventions applicable to people with HIV/ AIDS were outlined. The analysis of the levels of evidence showed that most of the articles studied were Level IV, i.e., the evidence for the hygiene interventions stemmed from well-designed cohort and case-control studies(11).

Hygiene is important for all individuals, and in order to implement hygiene guidelines, the health needs, emotional state of the patient and the way in which the educational strategy will be presented must be considered. Other factors to be analyzed include social practices, personal preferences, body image, socioeconomic status, motivation, health beliefs, cultural variables and physical condition of the individual(8).

Hand washing is one of the interventions that promote hygiene, since it can stop the transmission of pathogens that cause various diseases. Studies show that hand hygiene prevents or reduces the occurrence of infection ${ }^{(18,25)}$ and episodes of diarrhea so significantly that it is comparable to the beneficial effects of providing drinking water in low-income areas $^{(17)}$.

This represents an important intervention for people with HIV/AIDS, since diarrhea and other opportunistic infections are common and associated with increased viral load and reduced T CD4+ lymphocytes ${ }^{(18,21)}$. Taking a shower daily helps cleanse the body, because it removes the transient flora of microorganisms that accumulate on the skin throughout the day. This measure requires the use of treated water and proper basic sanitation, which includes: collection and treatment of sewage, street cleaning, solid waste management and pest control ${ }^{(18-19)}$.

Oral cavity hygiene is necessary so that oral diseases do not develop. Studies have shown that poor oral hygiene increases the risk of oral complications from HIV in- 
fection, which can result in worsened physical conditions and mental health status ${ }^{(24)}$. Among the oral problems that most affect these patients are candidiasis, gingivitis, periodontitis, hairy leukoplakia, herpes simplex and Kaposi's sarcoma. Opportunistic infections, including those that are bacterial, viral or fungal in origin, must receive specific pharmacological treatment to prevent resistance of the causative agents ${ }^{(12,23-24)}$.

The purpose of encouraging individuals to quit smoking is to avoid the development of oral diseases and diseases in other parts of the body, as well as reduce the characteristic odor that results from smoking and prevent nicotine addiction ${ }^{(24)}$.

In general, food hygiene involves measures to reduce the proliferation of microorganisms in food and kitchen utensils. Applying these measures is important due to the fact that people with HIV/AIDS are a high-risk group for contracting intestinal infections, which manifest in severe ways and are resistant to conventional pharmacological treatments ${ }^{(18-19,25-26)}$.

Proper disinfecting and handling of food is frequently referred to in the articles. Although ART is sometimes cited as something that interferes with gastrointestinal dynamics, studies of individuals with HIV/AIDS show that changes in the gastrointestinal tract, such as diarrhea, are more linked to enteropathogenic infections. Diarrhea mainly occurs due to lack of clean water and non-adoption of hygienic practices during food preparation and consumption ${ }^{(19,25-26)}$.

Precautions with meat were also noted, related to conservation, origin, characteristics and level of cooking, in order to avoid sources of infectious microorganisms $s^{(20,22,26-27)}$. Food hygiene begins at the time the shopping list is prepared, since it is while shopping that the characteristics of foods are observed. Choosing the place where foods are purchased should be based on the hygiene of employees, organization and cleanliness of the environment, and substandard services should be reported to health surveillance authorities. In addition to the expiration date, other characteristics of the food, such as packaging, consistency, color and odor, should be checked.

The appearance and condition of eggshells should also be inspected to see whether there are signs of contamination, and raw or undercooked eggs should never be eaten in order to prevent salmonellosis, a disease caused by the salmonella bacteria, which infects chicken eggs. Salmonella lives in the intestines of chickens and contamination can occur when eggs are laid, due to cracks in the shell. Cracked eggs should be discarded and eggs that will be consumed should be washed. Eggs can also be contami- nated while they are still being formed, making it impossible to distinguish a good egg from an infected one. To prevent the disease, eggs must be cooked, since salmonella dies at temperatures higher than or equal to 65 degrees Celsius ${ }^{(20,26,29)}$.

Milk occupies a prominent place among foods with high biological value in the human diet, but at the same time it is a potential substrate for the development of pathogenic microorganisms. Milk contamination by fecal coliform, salmonella or other microorganisms is a source of concern for public health authorities, and the use of pasteurized milk is a necessary food hygiene practice. Furthermore, cheese and yogurt should be made from pasteurized milk, and cheeses with a soft consistency contain excess moisture that can contribute to the proliferation of pathogenic microorganisms ${ }^{(20,26)}$.

Lack of access to treated water from the public water supply network, lack of basic sanitation and inadequate procedures for the disposal of animal and household waste can negatively influence the quality of life of those with HIV/AIDS, by facilitating contact with microorganisms that may constitute sources of disease $e^{(13,16,18-19,21,25)}$.

Not raising domestic animals and taking precautions with the waste they produce are important hygiene measures, since there is a close connection between opportunistic diseases and domestic animals, due to the fact that the latter can serve as vectors for infection. Among the opportunistic diseases transmitted by animals to people with HIV/AIDS, the most predominant in Brazil is toxoplasmosis, a cosmopolitan zoonosis caused by the protozoan Toxoplasma gondii. Transmission occurs primarily via the ingestion of oocysts present in the environment through final hosts, cats, or intermediaries, men, other non-feline mammals and birds $(22,25-27,30)$.

\section{CONCLUSION}

This study analyzed the scientific production on hygiene-related health interventions for adults with HIV/AIDS. Hygiene interventions encompassed personal, food and environmental aspects, totaling 34 hygiene practices. It is important that hygiene guidelines be emphasized for everyone, but especially for patients with HIV/AIDS, since they have immunodeficiency.

Hygiene guidelines should be formulated after ascertaining the life conditions of patients, as they may be subject to different privations that undermine the implementation of certain hygiene practices. Low socioeconomic level is a critical factor, because even if patients are given instruction and understand the importance of hygiene practices, they 
will be unable to put them into action because they lack the necessary resources to do so. In this context, social support networks become increasingly important, with an emphasis on intersectorality, so that the needs of these patients can be more easily met.

A limitation of this study was the absence of papers addressing the use of sharp instruments by patients, such as nail clippers, scissors and razors, since this is often a subject of interest for people living with HIV/AIDS and their families. Studies involving mental hygiene, collective hygiene and personal hygiene, with an emphasis on sexual practices, were not found either.

This paper mainly highlights the importance of hygiene on health, focusing on individuals who lack the bare minimum to survive, which heightens the urgency of the issue and incites further research, particularly in terms of strategies that promote hygiene practices for people with low education and socioeconomic status.

It stresses the role of health professionals to maintain the quality of life of people with HIV/AIDS, especially nurses, who play a decisive role as educators in the healthcare context. It must be borne in mind that health education activities related to proper hygiene practices require scientific knowledge and personalized interventions that involve the patient's family and that can be applied to each situation or context.

\section{REFERENCES}

1. Ministério da Saúde (BR), Secretaria de Vigilância em Saúde. Departamento de DST, AIDS e Hepatites Virais. Bol Epidemiol Aids DST. 2012 dez;l(1):1-60.

2. Alcântara KC, Lins JBC, Albuquerque M, Aires LM, Cardoso LPV, Minuzzi AL, et al. HIV-1 mother-to-child transmission and drug resistance among Brazilian pregnant women with high access to diagnosis and prophylactic measures. J Clin Virol. 2012;54(1):15-20.

3. Duarte PS, Ramos DG, Pereira JCR. Padrão de incorporação de fármacos antirretrovirais pelo sistema público de saúde no Brasil. Rev Bras Epidemiol. 2011;14(4):541-7.

4. Maliska ICA, Padilha MI, Vieira M, Bastiani J. Percepções e significados do diagnóstico e convívio com o HIV/AIDS. Rev. Gaúcha Enferm. 2009;30(1):8591.

5. Okeke EN, Wagner GJ. Aids treatment and mental health: evidence from Uganda. Soc Sci Med. 2013;92:27-34.

6. Cunha GH, Galvão MTG. Diagnósticos de enfermagem em pacientes com o vírus da imunodeficiência humana/síndrome da imunodeficiência adquirida em assistência ambulatorial. Acta Paul Enferm. 2010;23(4):526-32.

7. Brasileiro ME, Cunha LC. Diagnósticos de enfermagem em pessoas acometidas pela síndrome da imunodeficiência adquirida em terapia antirretroviral. Rev Enferm UERJ. 2011;19(3):392-6.

8. Potter PA, Perry AG. Fundamentos de enfermagem. Rio de Janeiro: Elsevier; 2013.
9. Roma I, Silva JA, Magolbo NG, Aquino RF, Marin MJS, Moravcik MYAD, et al. Analisando a percepção de uma população sobre higiene a partir de um jogo educativo. Rev Pesq Saúde. 2011;12(1):41-6.

10. Souza MT, Silva MD, Carvalho R. Revisão integrativa: o que é e como fazer. Einstein. 2010;8(1):102-6.

11. Melnyk BM, Fineout-OverholtE. Evidence-based practice in nursing \& healthcare: a guide to best practice. Philadelphia: Lippincott Williams \& Wilkins; 2011.

12. Shirlaw PJ, Chikte U, Macphail L, Schmidt-Westhausen A, Croser D, Reichart P. Oral and dental care and treatment protocols for the management of HIV-infected patients. Oral Dis. 2002;8(2):136-43.

13. Clasen TF, Roberts IG, Rabie T, Schmidt WP, Cairncross S. Interventions to improve water quality for preventing diarrhea [Review]. Cochrane Libr. 2009;1:1-73.

14. Lemos SS, Oliveira FA, Vencio EF. Periodontal disease and oral hygiene benefits in HIV seropositive and AIDS patients. Med Oral Patol Oral Cir Bucal. 2010;15(2):e417-21.

15. Gould DJ, Moralejo D, Drey N, Chudleigh JH. Interventions to improve hand hygiene compliance in patient care [Review]. Cochrane Libr. 2011;8:1-34.

16. Abubakar II, Aliyu SH, Arumugam C, Hunter PR, Usman N. Prevention and treatment of cryptosporidiosis in immunocompromised patients [Review]. Cochrane Libr. 2012;5:1-31.

17. Ejemot-Nwadiaro Rl, Ehiri JE, Meremikwu MM, Critchley JA. Hand washing for preventing diarrhea [Review]. Cochrane Libr. 2012;2:1-43.

18. Yallew WW, Terefe MW, Herchline TE, Sharma HR, Bitew BD, Kifle MW. Assessment of water, sanitation, and hygiene practice and associated factors among people living with HIV/AIDS home based care services in Gondar city, Ethiopia. BMC Public Health. 2012;12:1057.

19. Mugambe RK, Tumwesigye NM, Larkan F. Barriers to accessing water, sanitation and hygiene among people living with HIV/AIDS in Gomba and Mpigi districts in Uganda: a qualitative study. J Public Health. 2013;21(1):29-37.

20. Hoffman EW, Bergmann V, Shultz JA, Kendall P, Medeiros LC, Hillers VN. Application of a five-step message development model for food safety education materials targeting people with HIV/AIDS. J Am Diet Assoc. 2005;105(10):1597-604.

21. Lule JR, Mermin J, Ekwaru JP, Malamba S, Downing R, Ransom R, et al. Effect of home-based water chlorination and safe storage on diarrhea among persons with human immunodeficiency virus in Uganda. Am J Trop Med Hyg. 2005;73(5):926-33.

22. Vijayan VK, Kilani T. Emerging and established parasitic lung infestations. Infect Dis Clin North Am. 2010:24(3):579-602.

23. Fox JE, Tobias CR, Bachman SS, Reznik DA, Rajabium S, Verdecias N. Increasing access to oral health care for people living with HIV/AIDS in the U.S.: baseline evaluation results of the innovations in oral health care initiatives. Public Health Rep. 2012;127(2):5-16.

24. Rajabiun S, Fox JE, Mccluskey A, Guevara E, Verdecias N, Jeanty Y, et al. Patient perspectives on improving oral health-care practices among people living with HIV/AIDS. Public Health Rep. 2012;127(2):73-81.

25. Leite LHM, Waissmann W. Enteroparasitoses em pacientes ambulatoriais portadores de HIV/AIDS e abastecimento domiciliar de água. Rev Cienc Med. 2004;13(4):363-9.

26. Leite $L H$, Waissmann $W$, Veggi $A B$. Reprodutibilidade de um questionário para avaliação de conhecimentos, percepções e práticas em segurança sanitária alimentar de portadores de HIV/AIDS ambulatoriais. Cad Saúde Pública. 2007;23(4):971-6. 
27. Furtado JM, Smith JR, Belfort R, Gattey D, Winthrop KL. Toxoplasmosis: a global threat. J Glob Infect Dis. 2011;3:3:281-4.

28. ValcourV, Sithinamsuwan P, Letendre S, Ances B. Pathogenesis of HIV in the central nervous system. Curr HIV/AIDS Rep. 2011;8(1):54-61.

29. Teixeira RSC, Cardoso WM, Lopes ES, Rocha-e-Silva RC, Albuquerque AH, Horn RV, et al. Bacteriological investigation of microorganisms (Salmonella sp. and other Enterobacteriaceae) in common quails (Coturnix coturnix) submitted to different forced-molting procedures. Rev Bras Cienc Avic. 2013;15(1):47-52.

30. Nissapatorn V, Sawangjaroen N. Parasitic infections in HIV-infected individuals: diagnostic \& therapeutic challenges. Indian J Med Res. 2011;134(6):878-97.
Author's address:

Gilmara Holanda da Cunha

Rua Alexandre Baraúna, 1115, Rodolfo Teófilo

60430-160, Fortaleza, CE

E-mail: gilmaraholandaufc@yahoo.com.br
Received: 04.02.2014

Approved: 08.08.2014 